\title{
Erratum: Cooccurrence patterns of plants and soil bacteria in the high-alpine subnival zone track environmental harshness
}

\author{
Andrew J. King ${ }^{1 *}$, Emily C. Farrer ${ }^{2}$, Katharine N. Suding ${ }^{2}$ and Steve K. Schmidt ${ }^{3}$ \\ ${ }^{1}$ CSIRO, Acton, ACT, Australia \\ 2 Department of Environmental Science, Policy and Management, University of California at Berkeley, Berkeley, CA, USA \\ ${ }^{3}$ Department of Ecology and Evolutionary Biology, University of Colorado, Boulder, Boulder, CO, USA \\ ${ }^{*}$ Coresspondence:kin27g@csiro.au
}

\section{Edited by:}

Tim Daniell, The James Hutton Institute, UK

Keywords: erratum, community assembly, co-occurrence networks, niwot ridge, plant-microbe interactions

\section{A commentary on}

Co-occurrence patterns of plants and soil bacteria in the high-alpine subnival zone track environmental harshness by King, A. J., Farrer, E. C., Suding, K. N., and Schmidt, S. K. (2012). Front. Microbio. 3:347. doi: 10.3389/fmicb.2012.00347

There is an error in the information presented in Table 2. The 11th species should not be listed and the information for the 12th and 13 th species in columns $4-6$ of the table was incorrectly placed on the species directly above. Table 2 is a summary table and the data miss-attributed are correctly displayed in Figure 2.

Table 2 | A summary of subnival zone plant species' abundances, number of significant bacterial clade-associations and model fits.

\begin{tabular}{|c|c|c|c|c|c|c|c|c|c|c|}
\hline $\begin{array}{l}\text { Plant } \\
\text { species }\end{array}$ & $\begin{array}{l}\text { Average } \\
\text { (plants/ } \\
\text { site) }\end{array}$ & SD & Positives & Negatives & $\begin{array}{l}\text { Avg str } \\
\operatorname{cor}(r)\end{array}$ & $\begin{array}{l}\text { Correlation } \\
\text { with remote } \\
\text { index }(r)\end{array}$ & $\begin{array}{l}\text { Total cor } \\
\text { remote } \\
\text { upweight }\end{array}$ & $\begin{array}{l}\text { Avg corr } \\
\text { rm up }\end{array}$ & $\begin{array}{l}\text { Total cor } \\
\text { remote } \\
\text { downweight }\end{array}$ & $\begin{array}{l}\text { Avg corr } \\
\text { rm } \\
\text { down }\end{array}$ \\
\hline Bryophytes & 7.6 & 13.7 & 0 & 0 & 0 & 0.05 & 1 & 0.52 & 0 & 0 \\
\hline $\begin{array}{l}\text { Deschampsia } \\
\text { caespitosa }\end{array}$ & 5.7 & 14 & 1 & 1 & 0.39 & -0.27 & 0 & 0 & 2 & 0.50 \\
\hline $\begin{array}{l}\text { Kobresia } \\
\text { myosuroides }\end{array}$ & 3.5 & 15.3 & 2 & 0 & 0.39 & -0.16 & 1 & 0.05 & 5 & 0.41 \\
\hline Carex nardina & 3.2 & 5.7 & 2 & 1 & 0.31 & -0.25 & 1 & 0.01 & 2 & 0.43 \\
\hline Festuca rubra & 2.9 & 4 & 1 & 0 & 0.32 & 0.4 & 4 & 0.42 & 6 & 0.06 \\
\hline $\begin{array}{l}\text { Trifolium } \\
\text { Nanum }\end{array}$ & 2.7 & 10.6 & 0 & 0 & 0 & -0.04 & 0 & 0 & 0 & 0 \\
\hline $\begin{array}{l}\text { Elymus } \\
\text { scriberneri }\end{array}$ & 0.9 & 2.8 & 1 & 1 & 0.25 & 0.27 & 2 & 0.48 & 0 & 0 \\
\hline $\begin{array}{l}\text { Carex phaeo- } \\
\text { cephala }\end{array}$ & 0.9 & 2.9 & 2 & 0 & 0.31 & 0.13 & 3 & 0.40 & 0 & 0 \\
\hline
\end{tabular}

Received: 11 July 2013; accepted: 31 July 2013; published online: 21 August 2013. Citation: King AJ, Farrer EC, Suding KN and Schmidt SK (2013) Erratum: Cooccurrence patterns of plants and soil bacteria in the high-alpine subnival zone track environmental harshness. Front. Microbiol. 4:239. doi: 10.3389/fmicb.2013.00239 This article was submitted to Terrestrial Microbiology, a section of the journal Frontiers in Microbiology.
Copyright (C) 2013 King, Farrer, Suding and Schmidt. This is an open-access article distributed under the terms of the Creative Commons Attribution License (CC BY). The use, distribution or reproduction in other forums is permitted, provided the original author(s) or licensor are credited and that the original publication in this journal is cited, in accordance with accepted academic practice. No use, distribution or reproduction is permitted which does not comply with these terms. 